\title{
Cutting forces in gear machining by disk milling cutters
}

\author{
S. Pasternak ${ }^{1} \bullet$ Yu. Danylchenko ${ }^{2}$ \\ 1 - Haas Schleifmaschinen GmbH, Trossingen, Germany \\ 2 - Igor Sikorsky Kyiv Polytechnic Institute, Kyiv, Ukraine
}

Received: 15-December 2017 / Accepted: 23 February 2018

\begin{abstract}
Purpose. Experimental study of cutting force components in gear machining by disk milling cutter and taking into account the different machining strategies as well as determination of advantages and disadvantages of these strategies based on obtained experimental results.

Design/methodology/approach. This paper is dedicated to the experimental study of cutting force components and their variation in gear machining by disk milling cutter with different machining strategies as well as to the subsequent diskussion of obtained experimental results.

Findings. It was found that the known strategies for material removal, tool movement (its running-in or running-out) and tool engagement in gear machining by disk milling cutter have different force characteristics. This can lead to the different roughness and surface quality of the tooth flanks as well as to different tool wear rates and manufacturing costs. Thus, the consideration of the radial, axial and tangential forces is very important for a correct selection of an optimal machining strategy and optimal cutting parameters for each manufacturing task.

Originality/value. The experimental results show that the known strategies for gear machining by disk milling cutter have different force characteristics. This can influence machining quality and tool wear rate as well as lead to increase in manufacturing costs. It means that, in order to select a perfectly suitable machining method with the optimal process parameters for each individual manufacturing task and thereby to increase the efficiency of the gear manufacturing, the profound knowledge about achievable quality parameters and tool life are required.
\end{abstract}

Keywords: cutting force; disk milling cutter; gear machining

\section{Introduction}

There is a wide variety of gears and gearing mechanisms currently used in the automotive and machine-building industries. They differ by geometric parameters (number of teeth, flank line, tooth alignment and profile), gear quality (tooth profile, flank line and pitch accuracy, surface roughness) and material properties (hardness, weight, corrosion resistance) [1], [2], [3].

For an efficient single-piece and small batch production of different gears, flexible manufacturing technologies which can be implemented by using conventional cutting tools and machining centers are required. One of such technologies is gear cutting with profile-independent tools, such as disk milling cutters (see Fig. 1). It is characterized by a loose connection between the cutting tool and the tooth profile as well as provides possibilities to increase productivity and to reduce manufacturing costs [3], [4], [5], [6]. That is why, this machining process becomes more and more important nowadays.

Various methods for gear machining by disk milling cutters were developed and successfully implemented on the conventional machining centers [3], [4], [5], [6], [7], [8], [9], [10]. By analyzing these methods, it was found that they differ in strategies for material removal, tool movement and tool engagement as well as can be classified according to them [6], [11]. The analysis shows that some gear cutting methods are based on the similar or even same machining strategies. Furthermore, it was diskovered that none of the diskussed methods is perfect and universally applicable. Some of them, e.g. the Koganov's method [4], provide a higher manufacturing productivity and flexibility, and the others, e.g. the Wermeister's method [9], provide a better machining quality [6], [11].

The Koganov's method has already been studied theoretically and experimentally. Firstly, a mathematical model of the form-shaping kinematics (movements of the cutting tool relative to the workpiece) was developed for process simulation [6], [12]. After that, trajectories, velocities and accelerations of the machine tool components as well as material removal rates when gear cutting were calculated by using this mathematical model [6], [13], [14], [15].

$\triangle$ S. Pasternak

s.pasternak@multigrind.com 


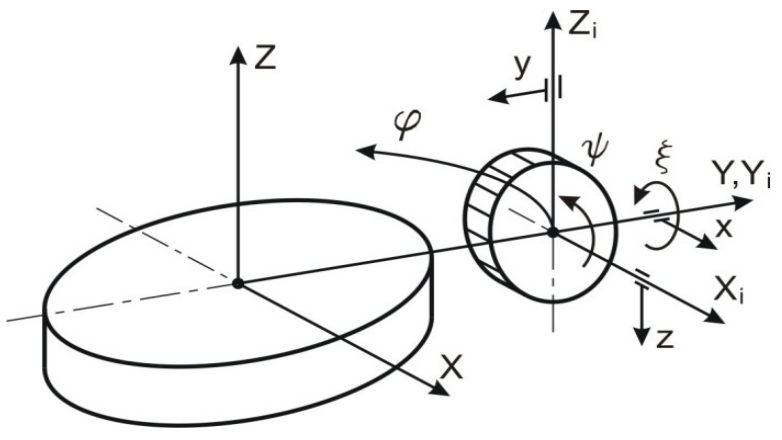

$a$

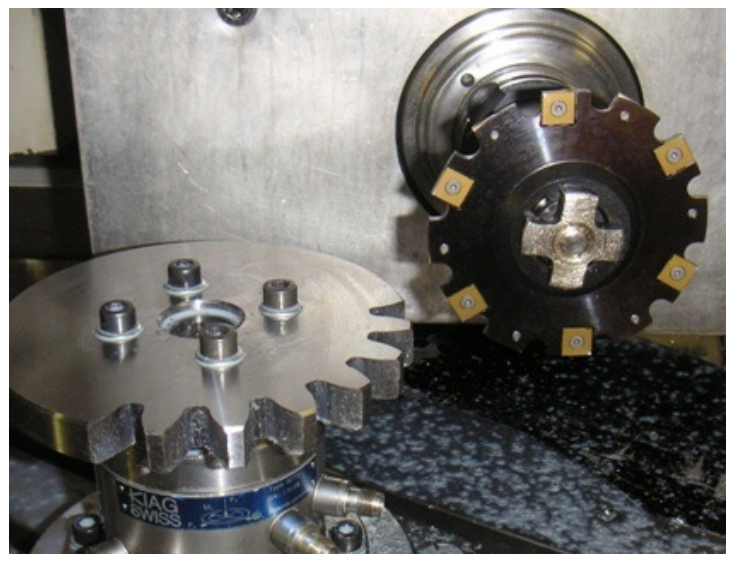

b

Fig. 1. Scheme of gear machining by disk milling cutter and its implementation [5], [6]

Finally, the cutting force components were measured when machining spur gears by using the Koganov's method and possible ways for the process optimization were proposed [6], [16]. Now, in order to be able to select an optimal machining strategy and suitable process parameters for each specific manufacturing task, similar theoretical and experimental studies of the other known methods for gear machining by disk milling cutter are to be conducted.

\section{Research objective}

The preliminary theoretical analysis of the different methods of gear cutting with disk-shaped tools shows that they could have certain advantages (e.g. high machining accuracy) and disadvantages (e.g. long manufacturing time) which define their optimal application area (gear type, geometric parameters, batch size etc.). In order to be able to select an optimal machining strategy for each specific manufacturing task (e.g. a small batch of chain wheels with cycloid profile) and to calculate optimal process parameters (e.g. feed, infeed, cutting speed), the knowledge about kinematic, dynamic and economic characteristics of the known methods for gear machining by disk milling cutter (such as material removal rates, cutting forces, surface quality, tool life etc.) is necessary. These data should be obtained by deep theoretical and experimental studies.

The present paper is dedicated to the experimental study of cutting force components and their variation in gear machining by disk milling cutter with different machining strategies as well as to the subsequent diskussion of obtained experimental results.

\section{Experimental setup}

Experimental study of gear machining by disk milling cutters was conducted in a 4-axis machining center Hermle UFW 1202 with the NC control Heidenhain TNC 426 at the Institute for Machine Tools of the Stuttgart University [6], [16].

In order to be able to measure orthogonal components of the cutting force during experiments, measuring equipment was built into the machining center. The main part of this equipment was a piezoelectric dynamometer Kistler 9272A centered and fixed on the turntable of the machine tool. Signals from the dynamometer, which were proportional to the cutting force components, were amplified by charge amplifiers Kistler 5015A10X0 and passed on to a measuring card Kistler PCI-6071. Then the amplified signals were processed and evaluated by using a program complex developed in the LabVIEW. Finally, the measurement results were visualized on a PC screen and stored on a hard disk [6], [16].

Workpieces used for experiments (see Fig. 2 a) were made out of high-quality steel C45 with a hardness of HB 180. They had a diameter $d_{w}=154 \mathrm{~mm}$ and a width $b_{w}=15 \mathrm{~mm}$. Due to their dimensions, the workpieces were perfectly suitable for manufacturing spur gears with a module $m=7 \mathrm{~mm}$ and a number of teeth $z=20$ as well as could be easily mounted onto the dynamometer described above. The relatively small gear width provided short production time and a sufficient rigidity for a high machining quality at the same time.

A cutting tool used for experiments (see Fig. 2 b) was a disk milling cutter Alberg 17210004 with a diameter $d_{f r}=$ $100 \mathrm{~mm}$ and a width $b_{f r}=4 \mathrm{~mm}$. Its dimensions were selected according to the gear geometry to be machined. The milling cutter was equipped with square uncoated inserts SNCX1102 made of cemented tungsten carbide MP30. Regarding the cutting geometry, the equipped inserts had a clearance angle $\alpha_{m}=7^{\circ}$ and a chip angle $\gamma_{m}=5^{\circ}$ on the main cutting edge (at the circumference) as well as a clearance angle $\alpha_{s}=2^{\circ}$ and a chip angle $\gamma_{s}=-2^{\circ}$ on the secondary cutting edges (at the frontal sides). The high heat resistance of MP30 made it possible to dispense with cooling lubrication during machining. This allowed a comfortable observation of the machining process and a more accurate detection of its force characteristics. 

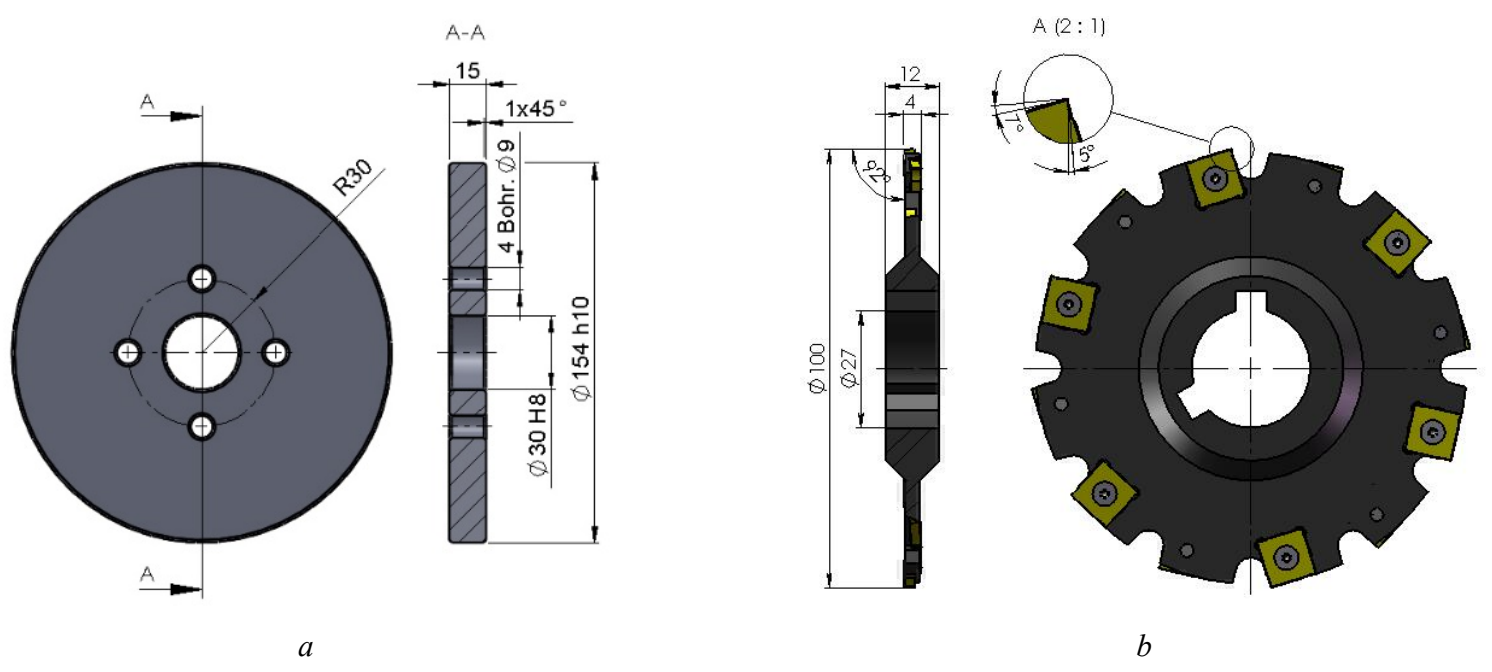

Fig. 2. Test workpiece (a) and disk milling cutter (b)

Following machining strategies previously introduced in [11] were used for the experimental study of cutting force components:

1) a combination of a continuous feed movement of the cutting tool along the flank line and its periodic infeed movement along the tooth gap profile (see Fig. 3 a) [3], [10];

2) a combination of a continuous feed movement of the cutting tool along the tooth gap profile and its periodic infeed movement along the flank line (see Fig. 3 b) [4], [6];

3) a continuous feed movement of the cutting tool in both directions - the workpiece material is simultaneously removed along the flank line and the tooth gap profile (see Fig. 3 c) 7 ;

4) a combination of two different machining strategies - the material removal is separately carried out along the flank line and then along the tooth gap profile (see Fig. 3 d) [8], [9].

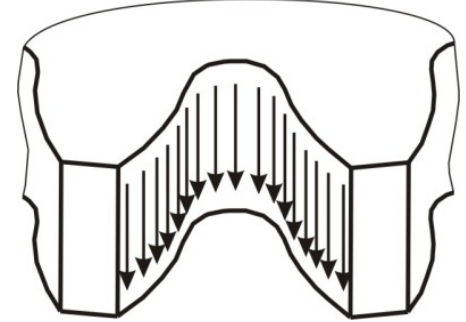

$a$

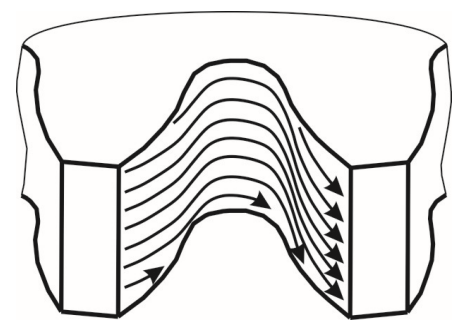

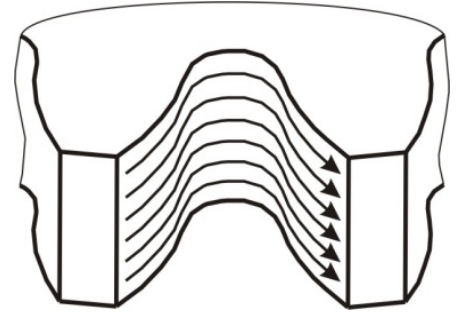

$\boldsymbol{b}$

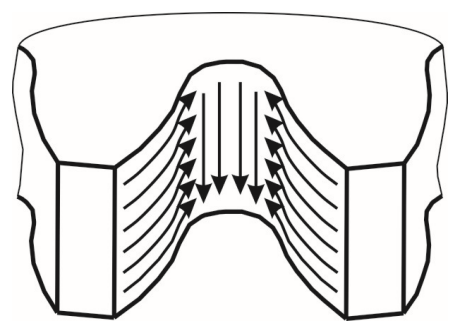

$\boldsymbol{d}$

Fig. 3. Strategies for material removal when machining the tooth gap

Moreover, the mentioned strategies differed in tool engagement. The symmetry axis of the milling cutter ran through the center of the workpiece (see Fig. 4 a) for the first three strategies (see Fig. $3 \mathrm{a}, \mathrm{b}$ and c) and tangential to the tooth flank profile (see Fig. 4 b) for the last one (see Fig. 3 d).

During machining the workpieces by using the mentioned strategies, the orthogonal cutting force components $F_{x}$, $F_{y}$ and $F_{z}$ were measured in the stationary coordinate system of the dynamometer (see Fig. 5). So far as the tool was constantly rotating around its own $X_{f r}$ axis and at the same time around the common $Z$ axis of the workpiece and the dynamometer, the corresponding rotation angles $\psi$ and $\varphi$ were used to calculate the axial, radial and tangential forces $F_{a}$, $F_{r}$ and $F_{t}$ on the tool cutting edge (see Fig. 5): 

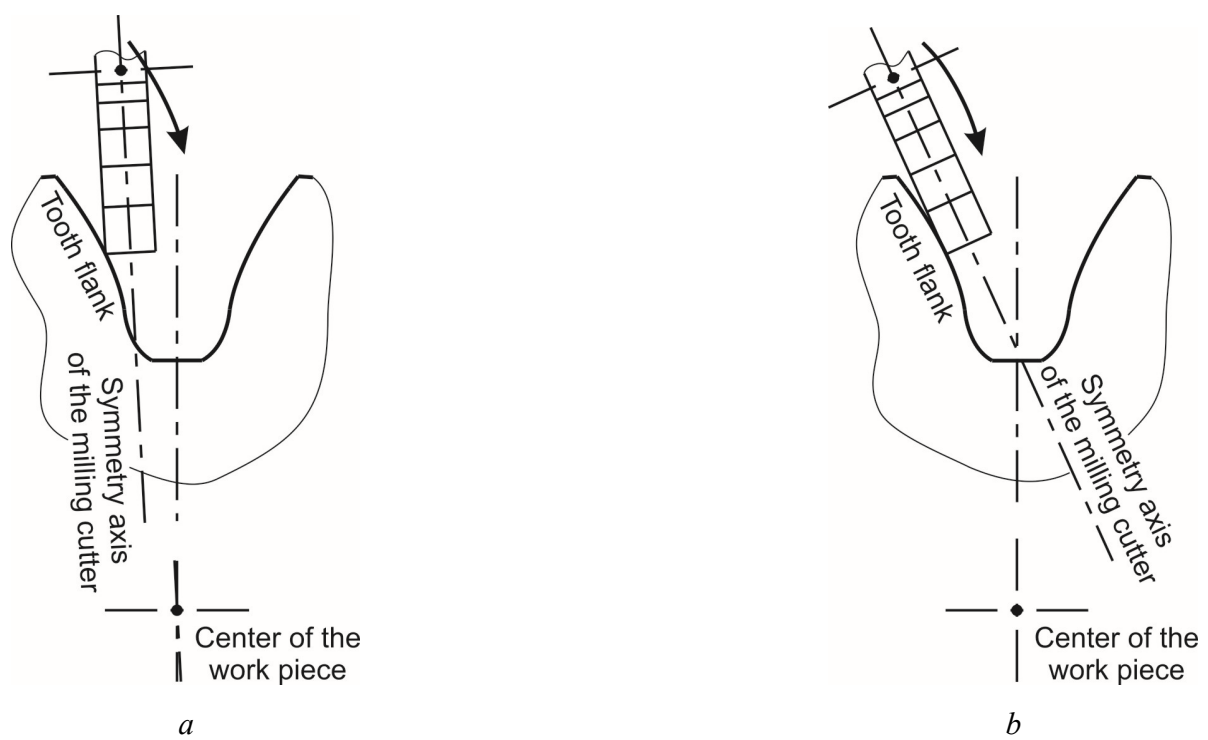

Fig. 4. Strategies for tool engagement when machining tooth flanks

$$
\begin{gathered}
F_{a}=F_{x} \cos \varphi-F_{y} \sin \varphi, \\
F_{r}=F_{z} \sin \psi+\left(F_{x} \sin \varphi+F_{y} \cos \varphi\right) \cos \psi, \\
F_{t}=F_{z} \cos \psi-\left(F_{x} \sin \varphi+F_{y} \cos \varphi\right) \sin \psi
\end{gathered}
$$

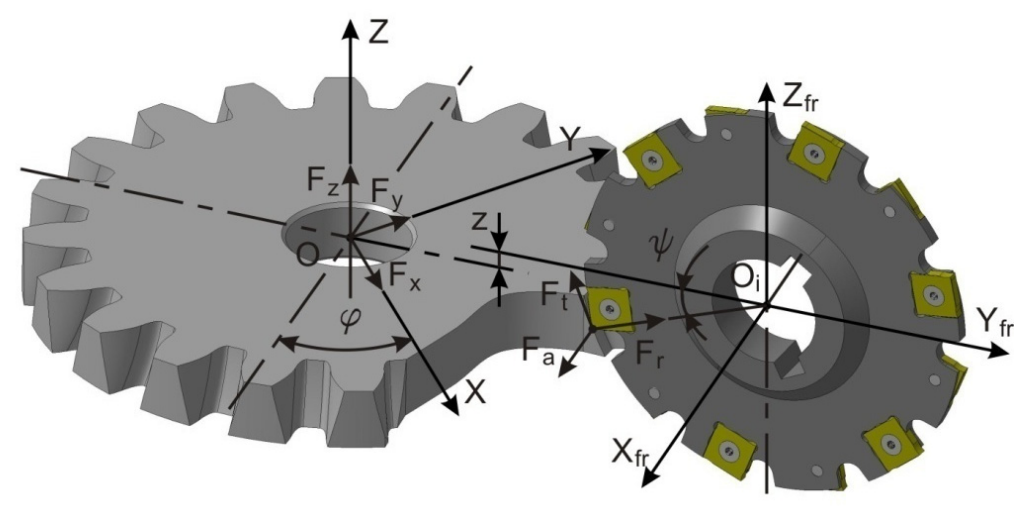

Fig. 5. Calculation of the cutting force components during machining the tooth gap

Although the force characteristics were measured in all vertical positions of the cutting tool $z$ relative to the workpiece (see Fig. 6 a), but only cutting force components at $z=0 \mathrm{~mm}$ were detailed analyzed (see Fig. $6 \mathrm{~b}$ ). Here, the entire tooth profile is generated and therefore the influence of the cutting force components on the tooth quality is particularly important. At $\mathrm{z}>0 \mathrm{~mm}$, the entire tooth profile is generated too, but the values of the cutting force components are much smaller (see $210 \mathrm{~s}$ to $300 \mathrm{~s}$ in Fig. $6 \mathrm{a}$ ). At $\mathrm{z}<0 \mathrm{~mm}$, the tooth profile is only partially produced and even the higher cutting force components (see $0 \mathrm{~s}$ to $180 \mathrm{~s}$ in Fig. 6 a) does not influence the tooth quality.

In addition, only absolute average values of the cutting force components per cutting edge or per tool revolution (yellow line in Fig. 6 b and c) were considered, because their instantaneous values were changing and it was difficult to represent and compare them (blue line in Fig. 6 b and c). This change in the cutting force components during one cut was associated with the change in the chip cross-section when milling. The change in the cutting force components from one cut to another during one tool revolution was caused by the inaccuracy of the cutting tool and the irregularity of its wear. The change in direction (sign) of the cutting force components can be explained by different material removal strategies when machining the tooth gap (running-in and running-out in Fig. $3 \mathrm{~b}$ and c) [11].

Fig. 7 shows changes in absolute average values of the axial, radial and tangential forces when machining an involute tooth gap ( $m=7 \mathrm{~mm}, z=20)$ according to the strategies shown in Fig. 3 and Fig. 4. As mentioned above, the cutting force components were always measured at the same vertical position of the cutting tool relative to the workpiece $\mathrm{z}=0 \mathrm{~mm}$. The exception was the machining strategy with the combined material removal (see Fig. $2 \mathrm{c}$ ). Here, the vertical position of the cutting tool was continuously changing from 0 (at $0 \mathrm{~s}$ ) to $2 \mathrm{~mm}$ (at $10 \mathrm{~s}$ in Fig. $7 \mathrm{c}$ ). 


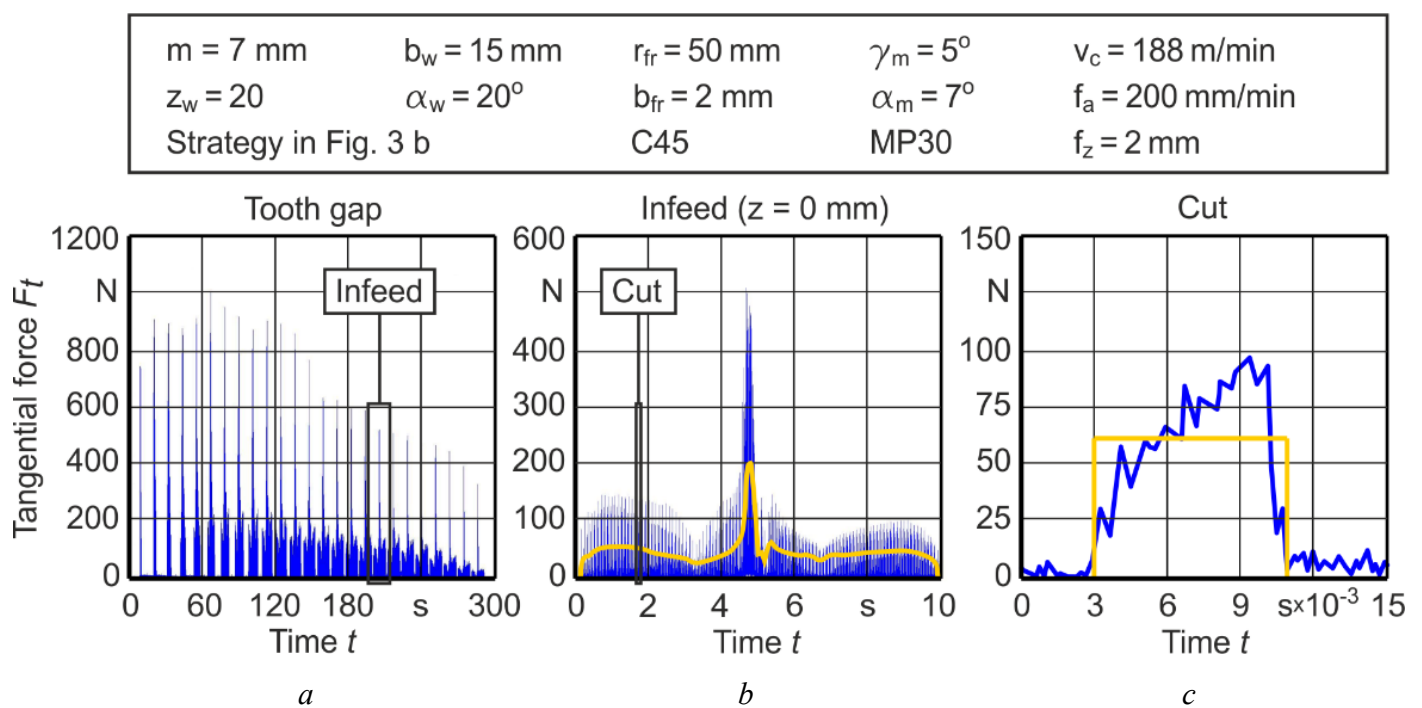

Fig. 6. Instantaneous (yellow line) and average tangential force (blue line) when machining the involute tooth gap

It should also be noted that in the case of the material removal along the flank line (see Fig. 3 a), the cutting force components were determined at $\mathrm{z}=0 \mathrm{~mm}$ but during different cutting strokes. Moreover, according to the tool engagement strategy shown in Fig. 4 b, only convex surfaces can be machined and only when the tool runs into the tool gap (see from $0 \mathrm{~s}$ to $4 \mathrm{~s}$ in Fig. $7 \mathrm{~d}$ ). The concave transition surfaces at the bottom of the tooth gap (see from $4 \mathrm{~s}$ in Fig. $7 \mathrm{~d}$ ) were machined according to the tool engagement strategy shown in Fig. 4 a.

Table 1 lists the feed rates at which the machining tests were performed. They were calculated in order to achieve approximately equal production times for the comparability in all considered cases. It should be noted that only the feed rates in the coordinate system of the workpiece are indicated in this table. In the coordinate system of the machine tool, these may differ due to the workpiece rotation.

Table 1

Feed rates and production times for different machining strategies

\begin{tabular}{|l|l|l|l|l|l|}
\hline \multicolumn{2}{|l|}{ Machining strategy } & \multicolumn{1}{|c|}{1} & \multicolumn{1}{c|}{2} & \multicolumn{1}{c|}{3} & \multicolumn{1}{c|}{4} \\
\hline \multirow{2}{*}{$\begin{array}{l}\text { Feed } \\
\text { along }\end{array}$} & Tooth profile & $200 \mathrm{~mm} / \mathrm{min}$ & $200 \mathrm{~mm} / \mathrm{min}$ & $200 \mathrm{~mm} / \mathrm{min}$ & $1 \mathrm{~mm}$ (infeed) \\
\cline { 2 - 6 } & Flank line & $2 \mathrm{~mm}$ (infeed) & $2 \mathrm{~mm}$ (infeed) & $12 \mathrm{~mm} / \mathrm{min}$ & $600 \mathrm{~mm} / \mathrm{min}$ \\
\hline \multicolumn{2}{|l}{ Production times per tooth } & $325 \mathrm{~s}$ & $374 \mathrm{~s}$ & $340 \mathrm{~s}$ & $353 \mathrm{~s}$ \\
\hline
\end{tabular}

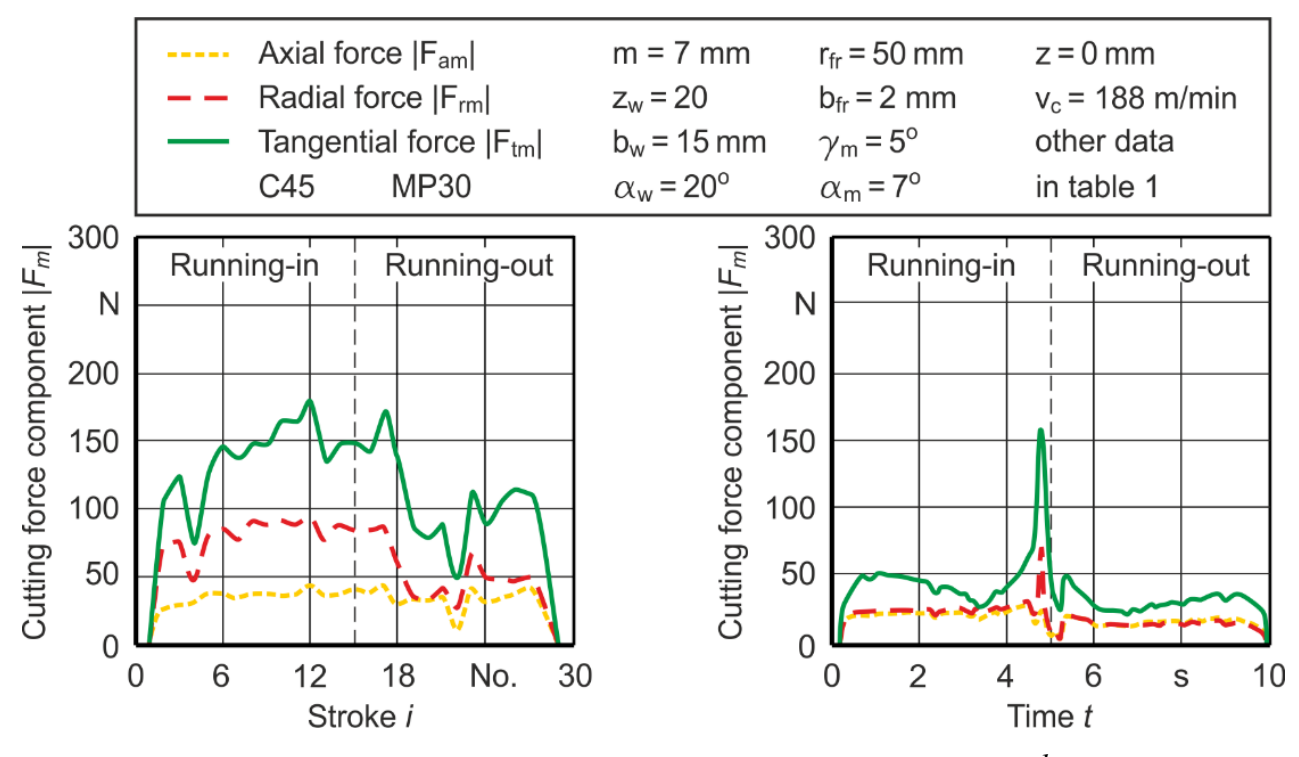




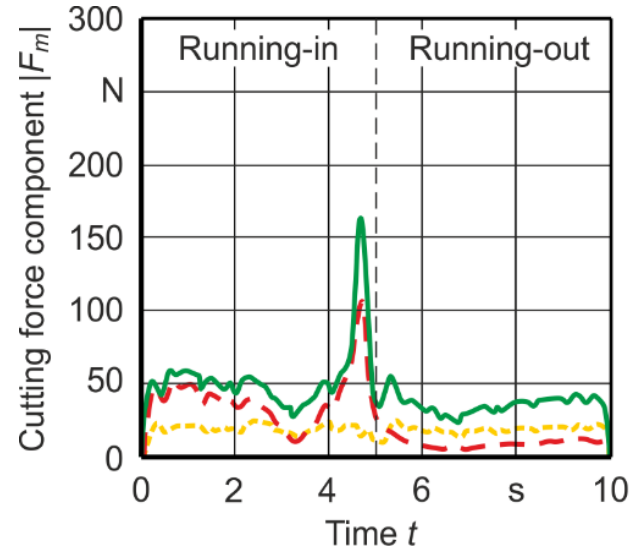

c

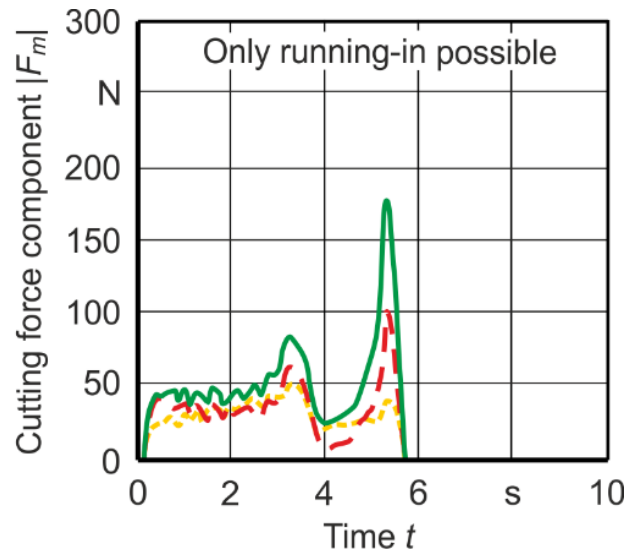

$d$

Fig. 7. Average values of cutting force components when gear cutting by using different strategies

\section{Diskussion of experimental results}

As it can be seen in Fig. 7, the force characteristics of the considered machining strategies have some similarities. The cutting force components (especially the radial and tangential forces) measured for the last three strategies (see Fig $3 \mathrm{~b}$, c and d) increase when machining at the bottom of the tooth gap (see $4 \mathrm{~s}$ to $5 \mathrm{~s}$ in Fig $7 \mathrm{~b}$, c and d). The reason for this is an increase in the material removal rate due to cutting with the entire tool width. This was previously detected in the simulation of the machining process [6], [14], [15]. When removing material along the tooth flank line (see Fig 3 a), not only the bottom of the tooth gap but also the first tooth flank is machined with the entire tool width. Therefore, the cutting force components are correspondingly higher (see $1^{\text {st }}$ to $15^{\text {th }}$ stroke in Fig. $1 \mathrm{a}$ ). The cutting force peaks can result in an increase in the mechanical stress and in an intensification of the tool wear. However, this must be verified by subsequent research efforts.

In addition to the similarities, the considered strategies for gear machining by disk milling cutters have certain differences in the cutting force components and their variation. For example, the values of the axial and radial forces arising when machining the opposite tooth flanks differ from each other. When the cutting tool runs into the tooth gap, the values of the axial force are approximately equal or lower than the values of the radial force (see $0 \mathrm{~s}$ to $4 \mathrm{~s}$ in Fig. $7 \mathrm{~b}$ and c). When it runs out from the tooth gap, the values of the axial force are higher than the values of the radial force (see $6 \mathrm{~s}$ to $10 \mathrm{~s}$ in Fig. $7 \mathrm{~b}$ and $\mathrm{c}$ ). This is due to the fact that the chip cross-section and the cutting angles differ from each other in the both cases. It influences the values of the cutting force components and can affect the tooth flank roughness and accuracy as well as the tool wear rates. As result, it can lead to an increase in manufacturing costs. When removing material along the flank line (see Fig 3 a), the resulting axial forces are always smaller than the radial forces (see Fig. 7 a). Also, the resulting peaks of the cutting force components are not significantly higher than their average values. This can be a prerequisite for ensuring a longer tool life and a better machining quality. These assumptions must also be verified by further research.

\section{Conclusion and prospects}

As it can be seen from the experimental results obtained in gear machining by disk milling cutters, the different strategies for material removal, tool movement (its running-in or running-out) and tool engagement have different force characteristics. This can lead to the different roughness and surface quality of the tooth flanks as well as and to different tool wear rates and manufacturing costs. Thus, the conclusion can be drawn that the consideration of the radial, axial and tangential forces is required for a correct selection of an optimal machining strategy and cutting parameters for each manufacturing task.

Further, similar machining tests with the simultaneous cutting force measurement have to be carried out for different workpiece materials and under variation of gear geometry and cutting parameters. Moreover, the technical and economic process characteristics of gear machining by disk milling cutters, such as the roughness and surface quality as well as the tool wear, should be studied for the different machining strategies. This knowledge will form a basis for planning and optimization of the machining process and for development of a corresponding software system as well as for design of cutting tools and machine tools in order to increase the competitive ability of the single-piece and shortseries gear's manufacturing. 


\section{Сили різання при обробці зубчастих коліс дисковими фрезами}

\section{С.І. Пастернак, Ю.М. Данильченко}

Анотація. Подані результати експериментальних досліджень силових характеристик прочесу нарізання зубчастих коліс дисковими фрезами. Проведено обробку зубчастого колеса із використанням 4-х стратегій, шуо відрізняються схемами зняття припуску. Встановлено відмінності та закономірності змін силових характеристик процесу обробки за різними стратегіями. Встановлено переваги і недоліки різних стратегій стосовно якості і продуктивності обробки, а також стійкості інструменту. Сформульовано проблеми, щьо потребують вирімення при виборі оптимальної стратегії обробки.

Ключові слова: сила різання; обробка зубчастих коліс; стратегія обробки; дискова фреза

\section{Силы резания при обработке зубчатых колес дисковыми фрезами}

\section{С.И. Пастернак, Ю.М. Данильченко}

Аннотация. Представлены результаты экспериментальных исследований силовых характеристик процесса нарезания зубчатых колес дисковыми фрезами. Проведена обработка зубчатого колеса с использованием 4-х стратегий, отличаюшихся схемами снятия припуска. Установлены отличия и закономерности изменения силовых характеристик процесса обработки по разным стратегиям. Установлены преимущества и недостатки разных стратегий по качеству и производительности обработки, а также стойкости инструмента. Сформулированы проблемы, требуюшие решения при выборе оптимальной стратегии обработки.

Ключевые слова: сила резания, обработка зубчатых колёс; стратегия обработки; дисковая фреза

\section{References}

1. Linke, H.: Stirnradverzahnung: Berechnung, Werkstoffe, Fertigung. München, Wien: Carl Hanser Verlag, 1996.

2. Litvin, F. L., Fuentes, A.: Gear Geometry and Applied Theory. $2^{\text {nd }}$ Edition. Cambridge, New York, Port Melbourne, Madrid, Cape Town: Cambridge University Press, 2004.

3. Roth, K.: Zahnradtechnik - Evolventen-Sonderverzahnungen zur Getriebeverbesserung: Evoloid-, Komplement-, Keilschräg , Konische-, Konus-, Kronenrad-, Torus-, Wälzkolbenverzahnungen, Zahnrad-Erzeugungsverfahren. Berlin, Heidelberg, NewYork: Springler Verlag, 1998.

4. Коганов И. А. Прогрессивная обработка зубчатых профилей и фасонных поверхностей. Тула: Приокское книжн. изво, 1970.

5. Heisel, U.; Pasternak, S.; Storchak, M.; Stehle, T.: Jede Verzahnung mit einem Werkzeug herstellbar. In: - die Maschine. 2009. - 5, $44-45 \mathrm{pp}$.

6. Pasternak, S.: Untersuchung und Optimierung der spandenden Fertigung von Verzahnungen mit profilunabhängigen Scheibenwerkzeugen. Dissertation Universität Stuttgart, 2016.

7. Спосіб нарізання зубчастих коліс. Благут Е. М., Данильченко Ю. М., Короткий Є. В., Кривошея А. В., Мельник В. Є., Пастернак С. І., Розенберг О. О. Патент UA15843, ICP B23F 5/00, Україна. Заявлено: 02.02.2006. Опубліковано: 17.07.2006.

8. Способ нарезания конических колес на станках с чпу. Нестеров, В. Я.; Демичев, В. А.; Гурвич, Е. Л.: Патент SU1720815, IPC B23F 9/00, СССР. Заявлено: 02.01.1989. Опубліковано: 23.03.1992.

9. Wermeister, G.; Scherbarth, S.: Neuer Weg zu präzisen Verzahnungen. WB Werkstatt und Betrieb. - 2011. 12. - 54-55 pp.

10. Zipse, H.; Siegler, R: Mit dem Mut zur Lücke. mav Kompetenz in der spanenden Fertigung. 2010. - 6, 26. p.

11. Пастернак С. І., Данильченко Ю. М., Хайзель У.: Machining strategies for gear cutting with disk-shaped milling tools. Вісник Національного Технічного Університету України "КПІ". Серія машинобудування. - 2015. - 74, №2. С. 61 - 66.

12. Данильченко Ю. М., Кривошея А. В., Пастернак С. І., Короткий С. В. Кінематика формоутворення циліндричних зубчастих коліс з заданим профілем дисковим інструментом. Вестник НТУУ “КПІ”. Серия машиностроения. - 2005. - 46. С. $104-108$.

13. Данильченко Ю. М., Кривошея А. В., Пастернак С. І. Математичне моделювання законів руху дискового інструменту при обробці зубчастих коліс довільного профілю. Вісник Національного Технічного Університету України "КПІ". Серія машинобудування. - 2006. - 49, С. 112 - 118.

14. Данильченко Ю. М., Пастернак С. І., Кривошея А. В. Продуктивність контурної обробки зубчастих ланок дисковим інструментом. Вестник НТУУ “КПІ”. Серия машиностроения. 2008) 53, 215-225.

15. Heisel, U.; Danylchenko, Yu.; Pasternak, S.; Storchak, M., Schaal, M.: Modellieren des Verzahnens mit Scheibenwerkzeugen. ZWF - Zeitschrift für wirtschaftlichen Fabrikbetrieb. 105 (2010) 7-8, 649-654.

16. Пастернак С. І., Данильченко Ю. М., Сторчак М. Г., Кривошея, А. В. Експериментальне дослідження контурної обробки циліндричних зубчастих коліс дисковим інструментом. Вісник Національного Технічного Університету України “ХПІ”. Тематичний випуск “Проблеми механічного приводу”, Харків: НТУ “ХПІ” - 2010. - 26, С. 94-101. 